\title{
Hubungan Penggunaan Kontrasepsi Pil dengan Usia Menopause
}

\section{Relationship of Contraceptive Utilization with Menopause Age}

\author{
Fitriyani, Ratna Djuwita
}

\section{Departemen Epidemiologi Fakultas Kesehatan Masyarakat Universitas Indonesia}

\begin{abstract}
Abstrak
Menopause merupakan menstruasi yang berhenti secara permanen yang disebabkan kehilangan fungsi folikel sel-sel telur. Wanita yang memasuki menopause mengalami penurunan hormon estrogen yang mengganggu aktivitas sehari-hari, bahkan menurunkan kualitas hidup. Penggunaan kontrasepsi pil berhubungan dengan penundaan usia dan keluhan menopause. Penelitian ini bertujuan mengetahui hubungan antara penggunaan kontrasepsi pil terhadap usia menopause. Penelitian ini menggunakan desain potong lintang. Populasi adalah wanita menopause di Pos Pembinaan Terpadu (Posbindu) Kota Depok. Sampel pada penelitian adalah wanita menopause yang berusia 45 - 60 tahun. Teknik pengambilan sampel secara purposive sampling subjek dengan besar sampel 407 orang. Analisis multivariat pada penelitian ini menggunakan cox proportional hazard model. Hasil analisis multivariat menunjukkan tidak ada hubungan antara lama penggunaan kontrasepsi pil terhadap usia menopause baik sebelum maupun sesudah dikontrol variabel kovariat, yaitu tingkat pendidikan. Namun demikian, masih diperlukan penelitian lain dengan menggunakan desain penelitian kohort prospektif untuk dapat melihat hubungan temporal antara lama penggunaan kontrasepsi pil terhadap usia menopause.

Kata kunci: Estrogen, kontrasepsi pil, usia menopause
\end{abstract}

\begin{abstract}
Menopause is marked with the permanent cessation of menstruation due to the loss of follicles. Earlier menopause will be likely to increase the risk factors relating to declined estrogen level, such as osteoporosis that can lead to early death. A woman entering menopause period often experiences declined estrogen hormone that causes her to have complaints or disturbances that hinder her daily activities and even reduce her quality of life. However, the use of oral contraceptive poses a correlation with the postponing of menopause age and complaints. The primary aim of this study was to examine the relation of oral contraceptive use and age at menopause. This was an observational study with cross-sectional study
\end{abstract}

design. Population in this study was all menopausal women in integrated training post (Posbindu), Depok. The sample was menopausal women among 45 - 60 years old. Sample was 407 menopausal women taken purposive sampling. The data was analysed by cox's proportional hazard analysed. The longer use of oral contraceptive was not associated with age at menopause before and after adjusted for confounding variable (education). However, another similar studies was still needed with prospective kohort study design to know temporality causal of longer use of oral contraceptive and age at menopause.

Keywords: Estrogen, oral contraceptive, age at menopause

\section{Pendahuluan}

Menopause adalah fase terakhir pendarahan haid seorang wanita berhenti sama sekali. Menopause merupakan suatu proses alamiah yang akan dialami oleh setiap wanita. ${ }^{1}$ Fase ini terjadi secara berangsur-angsur yang semakin hari semakin jelas penurunan fungsi kelenjar indung telur (ovarium). ${ }^{2}$ Pada saat terjadi menopause, indung telur (ovarium) tidak berespons lagi terhadap hormon gonadotropin sehingga siklus haid ini menjadi hilang atau merupakan suatu proses ketika ovulasi (pelepasan sel telur) di ovarium berhenti atau mengalami burning out. ${ }^{3}$

Menghadapi abad ke-21 ada beberapa masalah yang harus diperhatikan di negara kita yaitu peningkatan harapan hidup wanita sampai usia 80 tahun, disadari bahwa pada wanita pada usia 40 - 65 tahun memasuki masa klimakterium dengan segala dampak negatif dan

Alamat Korespondensi: Fitriyani, Departemen Epidemiologi Fakultas Kesehatan Masyarakat Universitas Indonesia Gd. A Lt.1 Kampus UI Depok 16424, Hp. 081210357652,e-mail: fitriyani030589@yahoo.co.id 
positifnya. Keadaaan sosial ekonomi memengaruhi faktor fisik, kesehatan dan pendidikan. Apabila faktor tersebut cukup baik akan memengaruhi beban fisiologis dan psikologis. ${ }^{4}$ Usia harapan hidup orang Indonesia terus meningkat dalam 25 tahun terakhir, yaitu dari 47,2 pada tahun 1971, menjadi 53,7 tahun 1980, kemudian 61,5 tahun pada tahun 1990, dan 66,7 tahun pada 1995. Penelitian-penelitian yang dilakukan di beberapa kota besar di Indonesia menunjukkan terjadi pergeseran umur menopause dari 46 tahun pada tahun 1980 menjadi 49 tahun pada tahun $2000 .^{5}$

Ada beberapa faktor yang memengaruhi usia menopause pada wanita, yaitu usia waktu mendapat haid pertama kali (menarche), jumlah anak, usia melahirkan anak terakhir, penggunaan kontrasepsi hormonal (oral), merokok, riwayat penyakit, status pekerjaan, pendapatan, dan konsumsi alkohol. ${ }^{1}$ Pemakaian kontrasepsi, khususnya kontrasepsi hormonal (oral/pil), pada wanita yang menggunakannya akan lebih lama atau lebih tua memasuki usia menopause. Hal ini dapat terjadi karena cara kerja kontrasepsi yang menekan fungsi indung telur sehingga tidak memproduksi sel telur. ${ }^{1}$ Penggunaan kontrasepsi oral (pil) merupakan salah satu cara untuk menghindari menopause dini pada wanita. Cara kerja kontrasepsi yang menekan fungsi indung telur sehingga tidak memproduksi sel telur. Angka harapan hidup di Kota Depok yang terus meningkat dan kejadian menopause dini yang kian meningkat akan menyebabkan wanita hidup dalam keadaan menopause yang lebih lama hidup dengan keadaan yang nonproduktif yang lebih rentan terkena penyakit seperti penyusutan tulang dan kardiovaskuler. Kontrasepsi hormonal oral pada wanita premenopause selain untuk kontrasepsi maka dapat juga digunakan untuk meminimalkan penyusutan tulang. Tujuan penelitian ini yaitu melihat hubungan penggunaan kontrasepsi pil terhadap usia menopause di Kota Depok tahun 2012.

\section{Metode}

Penelitian analitik dengan desain studi potong lintang yang mempelajari prevalensi, distribusi, hubungan penyakit dan paparan dengan cara mengamati status paparan, penyakit, atau karakteristik terkait kesehatan lainnya, secara serentak pada individu-individu dari suatu populasi pada satu saat. Lokasi penelitian ini adalah Pos Pembinaan Terpadu (Posbindu) di Kota Depok. Target populasi dalam penelitian ini adalah semua wanita menopause yang terdaftar di Pos Pembinaan Terpadu Lanjut Usia (Posbindu Lansia) di Kota Depok Provinsi Jawa Barat tahun 2012. Sampel penelitian adalah wanita yang telah menopause secara alami dengan kriteria inklusi yaitu usia 45 - 60 tahun, telah menikah, mempunyai anak baik yang lahir maupun yang lahir mati, bertempat tinggal di Kota Depok, dan bersedia menjadi responden penelitian di empat puskesmas Kota Depok yaitu Puskesmas Pancoran Mas, Sukmajaya, Depok Jaya, dan Beji. Kriteria eksklusi meliputi wanita yang pernah mengalami histerektomi (pengangkatan rahim), pernah terapi hormon sebelum menopause, merokok, konsumsi alkohol, dan pernah menjalani kemoterapi. Berdasarkan hasil perhitungan jumlah sampel dengan beda dua proporsi didapatkan besar sampel minimal sebanyak 160 orang. Total sampel yang dibutuhkan sebanyak 320 orang, untuk menghindari nonparticipation responden yang memengaruhi jumlah sampel penelitian yang didapatkan menjadi lebih sedikit dan untuk menjaga validitas data, maka sampel yang diambil ditambahkan $20 \%$ dari 320 menjadi 384 orang.

Teknik pengambilan sampel dengan random dari 36 puskesmas di Kota Depok dan terpilih empat puskesmas. Dari empat puskesmas ada 97 posbindu dengan jumlah lansia 6803 orang dan dipilih posbindu yang melakukan kegiatan pelayanan pada bulan Oktober dan November 2012 dan didapatkan 45 posbindu dengan jumlah lansia 2.074 orang. Jumlah lansia yang memenuhi kriteria inklusi dan eksklusi ada 407 lansia, yaitu wanita menopause yang berusia antara $45-60$ tahun, telah menikah dan pernah melahirkan, dan bertempat tinggal di Depok. Kriteria eksklusi antara lain pernah histerektomi, merokok, mengonsumsi alkohol, pernah terapi hormon sebelum menopause, pernah kemoterapi sebelum menopause dan pernah menggunakan kontrasepsi susuk/implan. Semua responden dimasukkan ke dalam analisis penelitian. Instrumen penelitian yang digunakan pada penelitian ini adalah kuesioner yang digunakan untuk pengambilan data primer meliputi identitas dan karakteristik responden yaitu nama responden, usia responden, tingkat pendidikan, usia menopause, riwayat penggunaan kontrasepsi oral/pil, lama penggunaan kontrasepsi pil, dosis estrogen pada kontrasepsi pil, beban kerja responden, usia mendapatkan haid pertama kali (menarche), jumlah anak, usia saat melahirkan anak terakhir kali, indeks massa tubuh, dan riwayat penggunaan kontrasepsi suntik. Tinggi badan pada penelitian ini diukur dengan menggunakan stadiometer. Analisis multivariat menggunakan cox proportional hazard model dengan variabel dependen kategorik untuk mengontrol faktor-faktor atau variabel confounding yang dapat memengaruhi kepada hasil penelitian yang sebenarnya.

\section{Hasil}

Dari analisis bivariat ditemukan variabel yang memenuhi kriteria kandidat model multivariat (nilai $\mathrm{p}<$ $0,25)$ adalah usia menarche, pendidikan, IMT, penggunaan suntik, lama penggunaan suntik (Tabel 1).

Untuk menguji confounding, dilakukan dengan melihat perbedaan nilai Hazard Ratio (HR) variabel independen utama yaitu lama penggunaan kontrasepsi pil pa- 
Tabel 1. Hasil Analisis Bivariat

\begin{tabular}{lll}
\hline Variabel & Kategori & Nilai p \\
\hline Penggunaan kontrasepsi pil & $\geq 5$ tahun & 0,96 \\
& $<5$ tahun & 0,79 \\
& Tidak pernah & 0,89 \\
& $\leq 12$ tahun \\
Usia menarche & $>12$ tahun & 0,23 \\
Pendidikan & Tinggi & \\
& Rendah & 0,002 \\
Status pekerjaan & Tidak & \\
& Ya & 0,44 \\
Jumlah anak & $>2$ & \\
& $\leq 2$ & 0,68 \\
Usia terakhir melahirkan & $>35$ tahun & \\
Indeks massa tubuh & $\leq 35$ tahun & 0,46 \\
& Lebih & 0,01 \\
Penggunaan suntik & Kurang & 0,66 \\
& Normal & 0,02 \\
Lama penggunaan suntik & Pernah & 0,006 \\
& Tidak pernah & \\
& $5-9$ tahun & 0,02 \\
& $<5$ tahun & 0,04 \\
& Tidak pernah & 0,01 \\
\hline
\end{tabular}

da model lengkap daripada nilai HR pada reduce model dengan dikeluarkan variabel kandidat confounding atau kovariat satu persatu. Dimulai dari variabel kovariat yang mempunyai nilai p paling besar. Jika variabel kovariat tersebut telah dikeluarkan dan ada perubahan nilai HR dari variabel independen utama sebelum mengeluarkan variabel kovariat dan setelah mengeluarkan variabel kovariat yaitu perubahan $>10 \%$, variabel tersebut dianggap sebagai confounding dan harus tetap berada di dalam model multivariat. Jika perubahan HR di bawah $10 \%$, variabel tersebut bukan variabel confounding dan dikeluarkan dari model (Tabel 2).

Hasil akhir analisis multivariat dapat dilihat bahwa didapatkan nilai $p$ pada variabel lama penggunaan kontrasepsi pil lebih dari 0,05 yang menunjukkan bahwa hubungan lama penggunaan kontrasepsi pil terhadap usia menopause tidak signifikan secara statistik. Dari nilai HR adjusted yang diperoleh pada penggunaan kontrasepsi pil $\geq 5$ tahun sebesar $\mathrm{HR}=0,90(95 \% \mathrm{CI}=0,52$ $-1,55)$ artinya tidak ada hubungan antara penggunaan kontrasepsi pil $\geq 5$ tahun terhadap usia menopause setelah dikontrol variabel pendidikan. Pada penggunaan kontrasepsi pil kurang dari 5 tahun diperoleh nilai $\mathrm{HR}=$ $0,90(95 \% \mathrm{CI}=0,57-1,42)$ artinya tidak ada hubungan antara penggunaan kontrasepsi pil kurang dari 5 tahun terhadap usia menopause setelah dikontrol variabel pendidikan (Tabel 3).

\section{Pembahasan}

Pada penelitian ini, rata-rata lama penggunaan kontrasepsi pil adalah 5,8 tahun dengan standar deviasi $=$ $5,79(95 \% \mathrm{CI}=4,49-7,13)$. Nilai minimal dan maksimal lama penggunaan kontrasepsi oral adalah 3 bulan dan 23 tahun. Seluruh wanita yang pernah menggunakan kontrasepsi pil menggunakan dosis rendah, kadar estrogen di bawah 0,05 milligram. Hasil penelitian ini berbeda dengan hasil penelitian sebelumnya di Belanda, proporsi wanita yang menggunakan kontrasepsi pil dengan dosis yang rendah adalah $28,2 \%$, sedangkan sisanya menggunakan kontrasepsil pil dosis tinggi atau di atas 0,05 milligram. ${ }^{6}$

Proporsi wanita menopause sebelum usia 49 tahun pada penelitian ini lebih tinggi daripada penelitian sebelumnya, yaitu sebesar $34,4 \%$, pada etnik AfrikaAmerika 23,7\%, pada etnik Hawai 30,7\%, dan pada etnik Jepang-Amerika 21,8\%. Proporsi wanita menopause secara alami sebelum usia 49 tahun adalah 22, $13 \% .^{7-9}$ Rata-rata usia menopause pada penelitian ini adalah 48,44 tahun dengan standar deviasi $=4,35$ (95\% $\mathrm{CI}=48,02-48,87)$. Usia menopause yang paling cepat pada penelitian ini adalah 32 tahun dan yang paling lama adalah 59 tahun. Rata-rata usia menopause pada penelitian ini lebih kecil daripada usia rata-rata menurut Departemen Kesehatan tahun 2005 yaitu 49 tahun. ${ }^{5}$ Rata-rata usia menopause alami terjadi pada usia 51,1 tahun. ${ }^{10}$ Usia rata-rata menopause pada wanita yang tidak pernah menggunakan kontrasepsi pil adalah 50,9 tahun sedangkan pada wanita yang pernah menggunakan kontrasepsi pil adalah 51 tahun. ${ }^{6}$ Di Belanda, rata-rata usia menopause secara alami adalah 50,3 tahun. ${ }^{11}$ Usia menopause antara seorang wanita dengan wanita lainnya tidak sama tergantung pada berbagai faktor.

Beberapa penelitian melaporkan wanita latin mengalami menopause alami lebih awal kurang lebih dua tahun daripada Kausian. Pada wanita Mexico, usia ratarata menopause adalah 48,2 tahun dan 47 tahun sedangkan pada wanita Peru dan Mayan mengalami menopause lebih awal berkisar antara 45 sampai 47 tahun walaupun paritasnya tinggi. Penelitian lain juga mengatakan wanita Afrika Amerika mengalami menopause alami 6 - 12 bulan lebih awal dibanding wanita Kausian dengan ratarata 49,3 tahun. ${ }^{12}$ Pada negara maju, usia rata-rata menopause sekitar 51 tahun. ${ }^{13}$ Wanita dikategorikan ke dalam menopause cepat jika usia menopausenya kurang dari 49 tahun dan digolongan dalam menopause lambat jika usia menopause diatas 53 tahun. ${ }^{14}$

Hasil akhir analisis multivariat dapat dilihat bahwa didapatkan nilai $\mathrm{p}$ pada variabel lama penggunaan kontrasepsi pil lebih dari 0,05. Hubungan lama penggunaan kontrasepsi pil terhadap usia menopause secara statistik tidak signifikan dan confidence interval yang melewati angka 1 . Kemungkinan karena kesalahan pengukuran dan mencari informasi pada lama penggunaan kontrasepsi pil. Dari nilai PR adjusted yang diperoleh pada penggunaan kontrasepsi pil $\geq 5$ tahun sebesar $\mathrm{PR}=$ $0,90(95 \% \mathrm{CI}=0,52-1,55)$, berarti wanita yang menggunakan kontrasepsi pil $\geq 5$ tahun berisiko 0,90 kali lebih 
Tabel 2. Full Model Analisis Multivariat dan HR Adjusted

\begin{tabular}{lllll}
\hline Variabel & Kategori & Nilai p & HR & 95\% CI \\
\hline Lama penggunaan kontrasepsi pil & $\geq 5$ tahun & 0,78 & 0,92 & $0,53-1,60$ \\
& $<5$ tahun & 0,50 & 0,85 & $0,53-1,36$ \\
& Tidak pernah & 0,78 & & \\
Usia menarche & & 0,35 & 1,18 & $0,83-1,67$ \\
Tingkat pendidikan & Lebih & 0,05 & 0,74 & $0,54-1,00$ \\
IMT setelah terakhir melahirkan & Kurang & 0,73 & 0,63 & $0,38-1,05$ \\
& Normal & 0,17 & & $0,74-1,51$ \\
Penggunaan kontrasepsi suntik & & 0,21 & 1,38 & $0,83-2,28$ \\
Lama penggunaan kontrasepsi suntik & $\geq 5$ tahun & 0,15 & 1,34 & $0,89-2,03$ \\
& $<5$ tahun & 0,20 & 1,38 & $0,83-2,28$ \\
& Tidak pernah & 0,20 & & \\
\hline
\end{tabular}

kecil untuk menopause dini daripada wanita yang tidak pernah menggunakan setelah mengontrol variabel tingkat pendidikan. Pada penggunaan kontrasepsi pil kurang dari 5 tahun berisiko 0,90 kali lebih kecil untuk mengalami menopause dini daripada wanita yang tidak pernah menggunakan kontrasepsi pil setelah mengontrol variabel tingkat pendidikan (nilai $\mathrm{PR}=0,90 ; 95 \% \mathrm{CI}=0,57$ $-1,42)$.

Penelitian lain, wanita yang menggunakan kontrasepsi pil menopause sekitar sepuluh bulan lebih lama dibandingkan wanita yang tidak menggunakan kontrasepsi pil. ${ }^{10}$ Pada wanita yang menggunakan kontrasepsi pil terjadi penurunan risiko menopause lebih cepat sebesar 0,8 kali daripada wanita yang tidak menggunakan kontrasepsi pil, $\mathrm{OR}=0,8(95 \% \mathrm{CI}=0,76-0,93)$ dengan median usia menopause pada wanita yang menggunakan kontrasepsi pil sebesar 51,6 tahun, sedangkan median usia menopause pada wanita yang tidak menggunakan kontrasepsi pil yaitu 51,0 tahun. ${ }^{12}$ Hormon estrogen dan progesteron sintetis berpengaruh menghambat ovulasi. Hasil penelitian berbeda dengan penelitian lain, tidak ada hubungan antara penggunaan kontrasepsi pil dosis rendah terhadap usia menopause, $\mathrm{HR}=1,0(95 \% \mathrm{CI}=$ $0,91-1,09)$ dan pada penggunaan kontrasepsi pil dosis tinggi antara 1 sampai 2 tahun didapatkan $\mathrm{HR}=1,05$ $(95 \% \mathrm{CI}=0,95-1,15)$ setelah mengontrol paritas, IMT, merokok, asuransi kesehatan, dan tahun lahir. ${ }^{6}$

Usia menarche untuk wanita yang tinggal di daerah urban lebih cepat daripada wanita di daerah perdesaan (rural), sedangkan usia menopause wanita di daerah urban lebih lambat dibandingkan wanita di daerah rural. ${ }^{15}$ Wanita yang mengalami menopause lebih cepat, dua kali lebih besar mengalami penurunan kualitas hidup, termasuk vitalitas yang buruk, fungsi fisik, kesehatan mental, dan persepsi kesehatan yang tidak lagi prima seperti saat sebelum mengalami menopause. Tidak hanya menyebabkan osteoporosis, menopause yang lebih cepat juga berisiko tinggi menyebabkan penyakit kardiovaskular. ${ }^{16}$ Hasil penelitian ini berbeda penelitian lain bahwa
Tabel 3. Model Akhir Analisis Multivariat dan HR Adjusted

\begin{tabular}{lcccc}
\hline Variabel & B & Nilai p & HR & 95\% CI \\
\hline $\begin{array}{l}\text { Lama penggunaan kontrasepsi pil } \\
\quad \text { ５ tahun }\end{array}$ & $-0,11$ & 0,70 & 0,90 & $0,52-1,55$ \\
$\quad<5$ tahun & $-0,11$ & 0,65 & 0,90 & $0,57-1,42$ \\
$\quad$ Tidak pernah & & 0,85 & & \\
$\quad$ Tingkat pendidikan & $-0,39$ & 0,02 & 0,69 & $0,51-0,94$ \\
\end{tabular}

wanita yang menggunakan kontrasepsi pil lebih dari sepuluh tahun berisiko untuk menopause lebih cepat 1,2 kali daripada wanita yang tidak pernah menggunakan kontrasepsi pil HR $=1,2(95 \% \mathrm{CI}=1,02-1,25) \cdot{ }^{6}$ Hasil penelitian ini sesuai dengan penelitian di Kota Pematang Siantar dengan menggunakan desain potong lintang (koefisien $=0,031$, nilai $p=0,02$ ) yang menunjukkan bahwa semakin lama seseorang menggunakan kontrasepsi pil, semakin tertunda usia menopause wanita tersebut. 1

Penurunan risiko menopause yang lebih cepat ditemukan pada wanita yang menggunakan kontrasepsi pil, tetapi penurunan risiko tersebut hanya sedikit karena pada penelitian ini, semua responden menggunakan kontrasepsi pil dosis rendah. ${ }^{6}$ Pemakaian kontrasepsi pil dosis tinggi sangat menekan konsentrasi FSH karena dosis estrogen dan progestin yang tinggi. Tipe kontrasepsi pil dosis rendah, menekan FSH dengan cara lebih moderat. Khusus dalam penggunaan kontrasepsi pil dosis tinggi ( $>0,05$ milligram) paling sedikit 3 bulan yang mengandung estrogen dan progesteron mengharapkan penundaan usia menopause. Perbedaan hasil penelitian ini dengan penelitian di Belanda karena perbedaan ras atau etnis. ${ }^{13}$ Usia menopause bervariasi oleh etnisitas sebesar 1,4\% di antara Kaukasia, Afrika Amerika, Hispanik, Cina, dan Jepang. ${ }^{17}$

Hubungan penggunaan kontrasepsi pil dan usia menopause tidak konsisten pada beberapa penelitian di beberapa negara. ${ }^{18}$ Ada hubungan antara penggunaan kontrasepsi pil terhadap penundaan usia menopause. ${ }^{10,19}$ Tidak ada hubungan antara penggunaan kontrasepsi pil 
terhadap penundaan usia menopause. ${ }^{14,20-22}$ Usia menopause dipengaruhi oleh tingkat folikel yang mengalami atresi. ${ }^{23}$ Atresia merupakan proses degenerasi yang disebabkan kehilangan ovum tanpa melewati ovulasi. Diperkirakan 99,9\% dari 500.000 oosit yang ada di dalam ovarium manusia ketika dilahirkan akan hilang karena atresia pada stadium perkembangan tertentu. ${ }^{24}$ Atresia tersebut dapat menurunkan produksi estrogen dan mempercepat terjadi menopause. ${ }^{23}$ Folikel yang mengalami atresia diperkirakan dipengaruhi oleh status hormonal seseorang yang diatur sistem neuroendokrin yaitu kelenjar pituitari. ${ }^{18}$ Stres dapat memengaruhi sistem neuroendokrin yang menyebabkan siklus menjadi tidak teratur. ${ }^{22}$

Bias seleksi merupakan distorsi efek yang timbul akibat proses atau cara tertentu dalam memilih subjek ke dalam populasi studi atau hilangnya subjek sebelum analisis data. Bias seleksi bisa terjadi pada semua desain studi. Peneliti berusaha mencegah terjadi bias seleksi yang dapat berasal dari perbedaan proporsi response rate antara kelompok terpajan dan kelompok tidak terpajan. Pada penelitian ini, jumlah subjek yang tidak dapat berpartisipasi 3 orang dari 334 orang pada kelompok tidak terpajan. Response rate pada kelompok terpajan sebesar 100,0\% dan response rate pada kelompok tidak terpajan $99,1 \%$.

Proporsi respons rate antara kelompok terpajan dan kelompok tidak terpajan hampir sama sehingga kemungkinan tidak terjadi bias seleksi yang akibat proporsi response rate yang sama. Bias informasi merupakan bias yang terjadi karena perbedaan dalam mutu dan cara pengumpulan data tentang pajanan atau penyakit dari kelompok studi. Kemampuan mengingat responden tentang riwayat masa lalu seperti usia menarche, berat badan sebelum menopause, dan setelah terakhir melahirkan merupakan sumber terjadinya bias informasi. Bias informasi yang terjadi pada penelitian ini merupakan bias misklasifikasi nondifferential karena kemampuan mengingat atau kesulitan mengingat tentang riwayat masa lalu tidak berbeda pada dua kelompok studi. Arah bias ini mendekati null hipotesis atau tidak ada hubungan yang mengakibatkan adanya underestimate. Bias informasi juga dapat berasal dari pewawancara karena subjektivitas dalam proses pengumpulan data. Untuk mencegah terjadinya bias ini, peneliti menggunakan instrumen kuesioner terstruktur dan mudah dipahami, menggunakan kuesioner yang sama antara kelompok terpajan dan kelompok tidak terpajan, melakukan pelatihan kepada pewawancara sebelum proses pengambilan data di lapangan.

Confounding merupakan bias dalam mengestimasi efek pajanan terhadap outcome akibat dari ketidaksebandingan antara kelompok terpajan dan kelompok tidak terpajan. Dalam suatu penelitian, biasanya terdapat variabel confounding yang memengaruhi besaran atau keeratan hubungan antara variabel independen dan variabel dependen. Pada penelitian ini, dilakukan upaya meminimalisasi confounding pada tahap mendesain penelitian yaitu dengan melakukan restriksi dengan menggunakan kriteria inklusi dan eksklusi serta mengumpulkan informasi atau variabel-variabel yang diduga sebagai potential confounders pada penelitian ini seperti usia menarche, tingkat pendidikan, status pekerjaan, jumlah anak, usia terakhir melahirkan, IMT, penggunaan kontrasepsi suntik, dan lama penggunaan kontrasepsi suntik. Pada tahap analisis, upaya untuk mengontrol confounding yaitu dengan analisis multivariat dengan menggunakan metode cox proportional hazard model, meskipun telah dilakukan upaya untuk mengontrol confounding, kemungkinan tetap ada variabel lain yang tidak diukur pada penelitian karena keterbatasan waktu, sumber daya, dan biaya penelitian yang menyebabkan adanya residual confounding.

Hasil penelitian hanya bisa digeneralisasi kepada populasi yang mempunyai karakteristik yang sama dengan sampel penelitian ini. Hal ini karena adanya restriksi yang dilakukan yaitu dengan kriteria inklusi, wanita yang pernah menikah yang mengalami menopause alami dan kriteria eksklusi yaitu wanita yang merokok, mengonsumsi alkohol, mengalami histerektomi (pengangkatan rahim), pernah terapi hormon sebelum menopause dan pernah menjalani kemoterapi sehingga kemungkinan adanya keterbatasan dalam menggeneralisasikan hasil studi.

\section{Kesimpulan}

Proporsi wanita yang menggunakan kontrasepsi pil $\geq$ 5 tahun dan menopause di sebelum 49 tahun ada 46,6\%, proporsi wanita yang menggunakan kontrasepsi pil $<5$ tahun dan menopause sebelum 49 tahun ada $45,7 \%$, proporsi wanita tidak pernah menggunakan kontrasepsi pil dan menopause sebelum usia 49 tahun dan menopause sebelum 49 tahun dan tidak pernah menggunakan kontrasepsi pil 51,1\%. Tidak ada hubungan antara lama penggunaan kontrasepsi pil terhadap usia menopause sesudah dikontrol variabel kovariat, yaitu pendidikan. Penggunaan kontrasepsi pil lebih dari 5 tahun dan kurang dari 5 tahun tidak memperlama atau memperpanjang usia wanita untuk menopause.

\section{Saran}

Diharapkan adanya penelitian serupa yang dilakukan dengan memperhitungkan variabel kebiasaan diet dan genetik atau riwayat menopause pada keluarga untuk mengetahui hubungan antara kebiasaan diet dengan usia menopause dan pengaruh riwayat usia menopause pada keluarga terhadap usia menopause. Hasil penelitian ini tidak menemukan adanya hubungan antara penggunaan 
kontrasepsi pil terhadap usia menopause. Hal ini kemungkinan karena adanya kelemahan pengukuran dan kelemahan dalam mengumpulkan informasi dalam penelitian ini. Oleh karena itu, diharapkan adanya penelitian serupa yang dilakukan dengan metode pengukuran dan pengumpulan informasi yang lebih baik.

\section{Daftar Pustaka}

1. Safitri A. Beberapa faktor yang mempengaruhi menopause pada wanita di Kelurahan Titi Papan Kota Medan Tahun 2009 [skripsi]. Medan: Fakultas Kesehatan Masyarakat USU; 2009 [diakses tanggal 2 Juli 2012]. Diunduh dari: http:// repository. usu.ac.id/ bitstream/123456789/ 14625/1 /09E01078.pdf

2. Larasati T. Kualitas hidup pada wanita yang sudah memasuki masa menopause. Depok: Fakultas Psikologi Universitas Gunadarma; 2012 [diakses tanggal 2 Juli 2012]. Diunduh dari: http://www.gunadarma. ac.id/library/articles/graduate/psychology/2009/Artikel_10504 128.pdf.

3. Malawat R. Pengaruh pendidikan kesehatan tentang menopause terhadap tingkat pengetahuan wanita menopause di Pedukuhan Geblagan Tamantirto Kasihan Bantul [skripsi]. Yogyakarta: Fakultas Kedokteran dan Ilmu Keperawatan Universitas Muhammadiyah Yogyakarta; 2010 [Diakses tanggal 4 Jul 2012]. Diunduh dari: http:// publikasi.umy.ac.id/ index.php/psik/ article/viewFile /2500/1159(4/7).

4. Levina P. Menopause: masalah dan penanggulangannya. Jakarta: Balai Penerbit FKUI; 2000

5. Departemen Kesehatan Republik Indonesia. Terjadi pergeseran umur menopause. 2006 [diakses tanggal 2 Jul 2012]. Diunduh dari: http://www.depkes.go.id/index.php?option=news\&task=viewarticle\& sid $=936 \&$ Itemid

6. de Vries E, den Tonkelaar I, van Noord PA, van der Schouw YT, te Velde ER, Peeteres PH. Oral contraceptive use in relation to age at menopause in the DOM cohort. Hum Reprod [serial on internet]. 2001 [cited 2012 Oct 7]; Vol. 16 (8); 1657-62. Available from: http://humrep.oxfordjournals.org/content/16/8/1657.pdf

7. Pokoradi AJ, Iversen L, Hannaford PC. Factors associated with age of onset and type of menopause in a cohort of UK Women. Am J Obstet Gyneco [serial on internet]l. 2011 [cited 2012 Dec 26]; 205(34); 1-13. Available from: http://download.journals.elsevierhealth.com/pdfs/journals/00029378/PIIS0002937811 002493.main-abr.pdf

8. Katherine DH, Leslie B, Brian H, Laurence K, Malcolm CP. Predictors of the Timing of Natural Menopause in the Multiethnic Cohort Study. Am J Epidemiol [serial on internet]. 2008 [cited 2012 Jan 12]; 167(11); 1287-94. Available from: http://aje.oxfordjournals.org/content/167/11/1287.full.

9. Douglas OH, Toyokawa S, Masaru U, Takahashi H, Katsumi K. Timing of Menopause, Reproductive Years, and Bone Mineral Density. Am J Epidemiol [serial on internet]. 1998 [cited 2012 Sept 24]; 148 (11); 1055-61. Available from: http://aje.oxfordjournals.org/content/148/11/1055.full

10. Stanford JL, Harteg P, Brinton LA. Factor influencing the age at of nat- ural menopause. Journal of Chronic Disease. 1987; 17: 287 - 302.

11. Marlies V, Frank JB, Bart CJM, Charlotte OM, Yvonne TS. Genes involved in initial follicle recruitment may be associated with age at Menopause. J Clin Endocrinol Metab [serial on in ternet]. 2011 [cited 2012 Dec 17]; 96(3): 473-9. Available from: http://jcem.endojournals .org/content/96/3/E473.full.pdf

12. Gold EB, Bromberger J, Crawford S, Samuels S, Gredale GA, Sioban S, et al. Factors associated with age at natural menopause in a multiethnic sample of midlife women. Am J Epidemiol [serial on internet]. 2001 [cited 2012 Sept 12]; 153(9): 865-74. Available from: http://aje.oxfordjournals.org/content/153/9/865.full.pdf

13. World Health Organization. Research on the menopause, progress in human reproduction research in the 1990s. Geneva: WHO; 1996.

14. Noord PV, Dubas JS, Dorland M, Bursma H, Velde E. Age at natural menopause in a population-based screening cohort: the role of menarche, fecundity and lifestyle factors. Fertility and Sterility. 1998; 68: 95102.

15. Wati'ah. Jangka reproduksi dan kajian faktor-faktor yang mempengaruhi pada wanita di Kabupaten Cirebon Provinsi Jawa Barat [Tesis]. Bogor: Institut Pertanian Bogor; 2011 [diakses tanggal 10 Juli 2012]. Diunduh dari: http://repository.ipb.ac.id/bitstream/handle/123456789/515 79/2011wat. pdsequen ce $=1$

16. Parazzini F. Premature ovarian failure: frequency and risk factors among women attending a network of menopause clinics in Italy. Int J Obstet Gynaecol [serial on internet]. 2003 [cited 2012 Jul 17]; 110(1); 59-63. Available from: http:// onlinelibrary. wiley.com /doi/ 10.1046/ j.1471 0528.2003.02129.x /full17/7

17. Luborsky JL, Meyer P, Sowers MF, Gold EB, Santoro N. Premature menopause in a multi-ethnic population study of the menopause transition. Human Reproduction. 2002; 18: 199-206.

18. Whelan EA, Sandler DP, McConnaughey DR, Weinberg CR. Menstrual and reproductive characteristics and age at natural menopause. American Journal of Epidemiology. 1990; 131 (4): 625-32.

19. Keep Van PA, Brand PC, Lehert P. Factor affecting the age at menopause. Journal of Biosocial and Science. 1979: Suppl37 - 55.

20. McKnlay SM. The normal menopause transition: an overview. Journal of the Climacteric and Post Menopause. 1996: 137 - 45.

21. Cramer DW, Harlow BL, Xu H, Fraer C, Barbieri R. Cross-sectional and case controlled analyses of the association between smoking and early menopause. Maturitas. 1995; 22: 79-87.

22. Bromberger JT, Mattehws KA, Kuller LH, Wing RR, Meilahn EN, Platinga P, et al. Prospective study of the determinants of age at menopause. Am J Epidemiol [serial on internet]. 1997 [cited 2012 Dec 27]: 145 (2): 124-33 . Available from: http://aje.oxfordjournals. org/content/145/2/124.full.pdf.

23. Weinstein M, Gorrindo T, Riley A, Mormino J, Nienfeldt J, Singer B, et al. Timing of menopause and patterns of menstrual bleeding. American Journal of Epidemiology. 2003; 158: 782-91.

24. Turner CD, Bagnara JT. Endokrinologi umum. Harsojo, penerjemah; Moeljono E, editor. Yogyakarta: Airlangga University Press; 1988. 